\title{
Low prevalence of splenic mycobacteriosis in migratory striped bass Morone saxatilis from North Carolina and Chesapeake Bay, USA
}

\author{
Mark A. Matsche ${ }^{1, *}$, Anthony Overton ${ }^{2}$, John Jacobs ${ }^{3}$, Matt R. Rhodes ${ }^{4}$, \\ Kevin M. Rosemary ${ }^{1}$ \\ ${ }^{1}$ Maryland Department of Natural Resources, Cooperative Oxford Laboratory, Oxford, Maryland 21654, USA \\ ${ }^{2}$ East Carolina University Harriot College of Arts and Science, Howell Science Complex, Greenville, \\ North Carolina 27858, USA \\ ${ }^{3}$ NOAA/NCCOS/Cooperative Oxford Laboratory, Oxford, Maryland 21654, USA \\ ${ }^{4}$ JHT Inc., Cooperative Oxford Laboratory, Oxford, Maryland 21654, USA
}

\begin{abstract}
Mycobacteriosis is a chronic bacterial disease causing an ongoing epizootic in striped bass Morone saxatilis in Chesapeake Bay, USA. Prevalence of disease is high in pre-migratory fish, and multiple species of Mycobacterium spp. have been isolated. However, prevalence of mycobacteriosis in the coastal migratory population is unknown and is of concern to multiple coastal states, as disease-related mortality may impact the long-term health of the population. Histological examinations of spleens collected from fish caught by recreational anglers during the winter fishery in coastal North Carolina $(2005-2006, n=249)$ and during the spring fishery in Chesapeake Bay $(2006, n=120)$ indicated a low prevalence of mycobacteriosis (6.8\% of all fish examined) in comparison to smaller, pre-migratory Chesapeake Bay fish. Genus-level PCR and subsequent sequencing of the 16-23S intergenic transcribed spacer (ITS) region revealed that all bacteria were phylogenetically related, but species is unknown. Location of survey, gender of fish, and total length of fish had no significant effect on prevalence of mycobacteriosis, parasitic granulomas, or the density of splenic granulomas $(p>0.05)$. These results may indicate that either granulomas resolve after Chesapeake Bay fish enter the coastal migratory population, or that there is disease-related mortality among pre-migratory Chesapeake Bay fish.
\end{abstract}

KEY WORDS: Mycobacteriosis · Striped bass · North Carolina $\cdot$ Chesapeake Bay $\cdot$ Migratory

\section{INTRODUCTION}

Mycobacteriosis is a chronic progressive disease currently affecting a large proportion of adult Chesapeake Bay (USA) striped bass Morone saxatilis. This ongoing epizootic was first detected in 1997 (Heckert et al. 2001, Rhodes et al. 2001) as a result of investigations of moribund fish. The prevalence of mycobacteriosis has since been reported in $>50 \%$ of Chesapeake Bay striped bass based on presence of visceral granulomatous inflammation with acid-fast bacilli, a hallmark mycobacterial lesion, and up to $75 \%$ using more sensitive molecular techniques (Overton et al. 2003, Kaattari et al. 2005). In addition, a high proportion of ulcerative skin lesions has been reported from infected fish (Rhodes et al. 2001, Overton et al. 2003). Onset of this disease is at least Age 1, and prevalence increases in both sexes to about Age 5, after which prevalence seems to decline markedly in females (Gauthier et al. 2008). To date, at least 13 species of mycobacteria have been identified from Chesapeake Bay striped bass, the most common being Mycobacterium shottsii, and multiple mycobacterial infections in a single fish are typical (Heckert et al. 2001, Rhodes et al. 2004, Stine et al. 
2010). While mycobacteriosis has been documented in archived tissue samples collected prior to 1997 from Chesapeake Bay striped bass (Jacobs et al. 2009b), historical prevalence is unknown. The ongoing epizootic concerns fisheries managers because of the potential ecological and economic impacts that may result from this disease (Gauthier et al. 2008).

Because the majority of recent mycobacteriosis research in Chesapeake Bay has focused on striped bass presumed to be pre-migratory, the prevalence of disease in the coastal migratory population has not been directly addressed. Migratory behavior patterns appear to be age- and sex-dependent and may be density-dependent as well (Mansueti 1961, Kohlenstein 1981, Secor \& Piccoli 2007). A larger proportion of females from Chesapeake Bay may undergo migrations and at a younger age than males (Dorazio et al. 1994, Secor \& Piccoli 2007), and these age- and sexdependent differences in migratory behavior may affect disease state in older fish.

There are 3 general stocks of striped bass along the US Atlantic Coast: Hudson River (New York), Chesapeake Bay, and Roanoke River (North Carolina). These fish typically spend their first years maturing in their natal estuaries and then become part of the migratory stock in the Atlantic Ocean. The Hudson River and Chesapeake Bay striped bass collectively contribute $>95 \%$ of the migratory fish. Most of these migratory fish $(\sim 73 \%)$ originate from Chesapeake Bay (Wirgin et al. 1993). There is some evidence that striped bass spawned in the tributaries of Albemarle Sound (North Carolina) and Roanoke River make minor contributions to the migratory stock (Chapoton \& Sykes 1961). The migratory fish (generally $>500 \mathrm{~mm}$ total length, TL) move northward during spring and spend summer in coastal waters off the northeast coast of the USA. During fall and winter, they return south to overwinter off the coasts of Virginia and North Carolina (Boreman \& Lewis 1987). Intermixing of Chesapeake Bay fish with Hudson River and Roanoke River-Albemarle Sound stock during migrations (Berggren \& Lieberman 1978) creates the potential for widespread transmission of this disease. This is a concern to multiple mid-Atlantic and New England states, as diseaserelated mortality may impact the long-term health of the fish population.

Concern over mycobacteriosis has prompted surveys for disease or infection in striped bass from estuaries outside Chesapeake Bay. Mycobacteriosis has been reported from Delaware Bay striped bass (Ottinger et al. 2007), and Mycobacterium spp. infections have been reported from Roanoke River and Long Island Sound striped bass (Stine et al. 2009), but mycobacteriosis has not been studied previously in the coastal migratory striped bass population. Information on disease prevalence in the coastal migratory population of striped bass is necessary to understand the distribution and potential impact of mycobacteriosis throughout their range. The goal of this study was to address this gap in knowledge by determining apparent prevalence of splenic mycobacteriosis in fish examined from recreational angler surveys.

\section{MATERIALS AND METHODS}

Fish collection and histology. Striped bass were collected weekly from December 2005 to February 2006 at the Oregon Inlet Fishing Center (OIFC), Manteo, North Carolina, and from April to May 2006 at a fillet station located at Tilghman Island (TI), Chesapeake Bay, Maryland. Fish were sampled from recreational fishermen who brought their daily catches to the fish cleaning stations at OIFC and TI (Fig. 1). Fish sampled at OIFC were presumably captured in the Atlantic Ocean 0.0 to $4.8 \mathrm{~km}$ from the shoreline, as no fishing for striped bass is permitted in the US Exclusive Economic Zone, while fish sampled from TI were captured within Chesapeake Bay. TL and sex were determined for each fish.

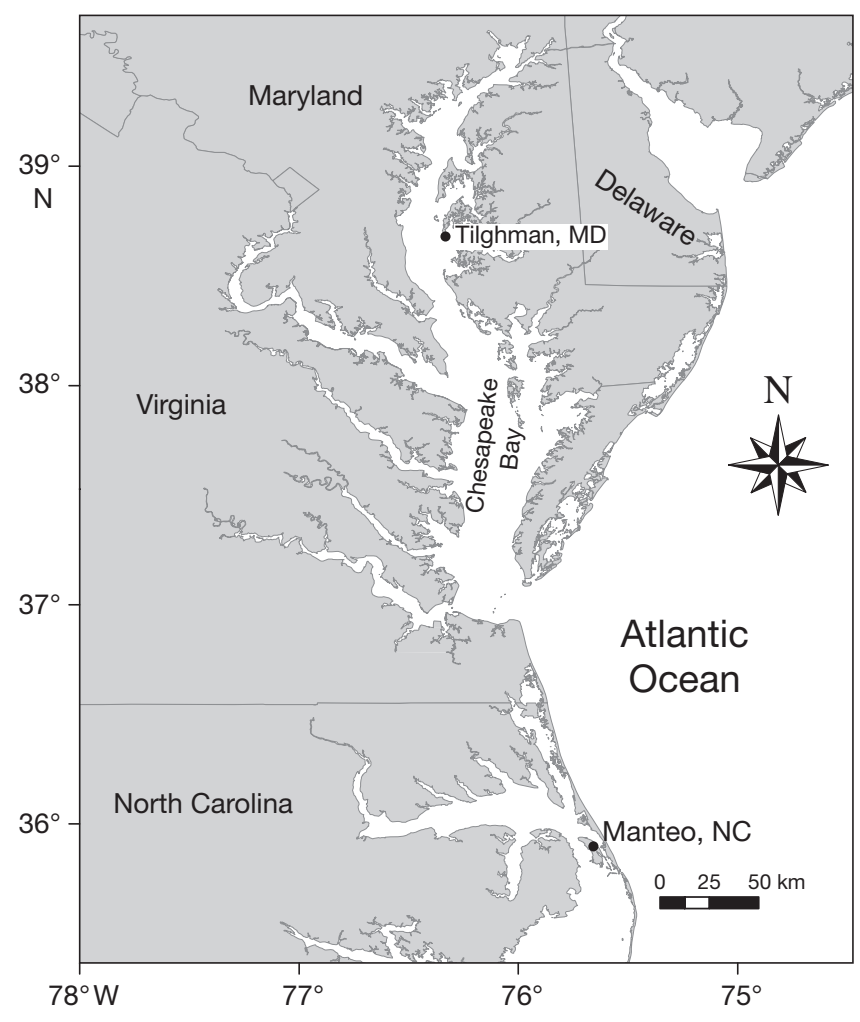

Fig. 1. Striped bass angler survey locations for prevalence of mycobacteriosis: Oregon Inlet Fishing Center, Manteo, North Carolina (December 2005 to February 2006) and Tilghman, Maryland (April to May 2006), USA 
Spleen was removed and fixed in 10\% neutralbuffered formalin for a minimum of $1 \mathrm{wk}$ before processing. Six non-contiguous cross-sections of spleen approximately $0.5 \mathrm{~cm}$ thick were randomly selected along the length of the organ and processed for routine paraffin infiltration, and 2 sections were cut at $7 \mu \mathrm{m}$ (Presnell \& Schreibman 1997). From each fish, 1 section was stained with Ziehl-Neelsen (ZN) acid-fast stain, and a second section was pretreated with $10 \%$ periodic acid $\left(\mathrm{HIO}_{4}\right)$ for $24 \mathrm{~h}$ and then stained with Ziehl-Neelsen (PZN; Nyka \& O'Neill 1970). Additional select sections were cut and stained with hematoxylin and eosin (HE), and all slides were examined on an Olympus BX50 light microscope.

Splenic tissues were examined for the presence of granulomas, which were defined as focal lesions containing epithelioid or spindle cells (Gauthier et al. 2003). Granulomas were enumerated from $\mathrm{ZN}$ and PZN-stained tissue sections according to the following categories: (1) acid-fast positive $(\mathrm{AF}+)$ if acid-fast bacilli were visible following ZN or PZN staining; (2) non-parasitic granulomas (NPG) if no parasites were visible in $\mathrm{AF}+$ or $\mathrm{AF}$ - granulomas; or (3) parasitic granulomas (PG). Prevalence of mycobacteriosis was determined as the proportion of fish with at least $1 \mathrm{AF}+$ granuloma.

Density of splenic granulomas was used as a measure of lesion severity. Slides containing splenic tissue were digitized on a document scanner, and ImageJ version 1.41 software (National Institutes of Health) was used to automatically delimit and determine total area of all splenic tissue on each slide from the digital images. For each fish, the number of granulomas and area of splenic tissue examined was summed from the ZN- and PZN-stained tissues, and the density of granulomas in the spleen was then determined by dividing the total number of granulomas by the total area of splenic tissue examined. Densities were determined for the following granuloma categories: (1) $\mathrm{AF}+$; (2) NPG; and (3) PG.

PCR, sequencing, and analysis. Species identification was attempted via extraction and amplification of DNA from AF+ paraffin-embedded tissues (Jacobs et al. 2009b, Stine et al. 2009). Briefly, the microtome was sterilized with $70 \% \mathrm{ETOH}$, and new, sterile blades were used for sectioning each block. After removal of several sections from the block's surface, 3 serial $5 \mu \mathrm{m}$ sections were cut, specific tissue sections segregated when possible, captured on a sterile wooden applicator, and transferred directly to sterile $1.5 \mathrm{ml}$ micro-centrifuge tubes. Sections were deparaffinized with xylene, and DNA was extracted with a Qiagen DNeasy kit according to the manufacturer's instructions for paraffin-embedded tissues, with some modification. Three ethanol (100\%) rinses were performed after the use of xylene for paraffin removal, followed by complete evaporation in a vacuum centrifuge for $15 \mathrm{~min}$. Elution from spin filters was performed twice to a total volume of $70 \mu$ l. Paraffin-embedded splenic tissue from a single fish challenged with Mycobacterium marinum was used as an extraction control. Samples were screened for the presence of mycobacteria using a real-time PCR assay targeting a genus-specific region of the ribosomal 16-23S intergenic transcribed spacer (ITS) region (Bruijnesteijn van Coppenraet et al. 2004, Jacobs et al. 2009b, Stine et al. 2009). Positive samples were gel extracted and purified using a Qiagen QIAquick Gel extraction kit. Sequencing was performed at the University of Maryland, Center of Marine Biotechnology BioAnalytical Services Laboratory. All sequencing was performed on an ABI 3130 XL Genetic Analyzer (Applied Biosystems) using the dye terminator method.

Sequences were aligned to our own database, and similarity was calculated using the freeware BioEdit (Hall 1999). All sequences were also blasted in GenBank to confirm results. Phylogenetic analysis was conducted using the software Mega 4 (Tamura et al. 2007). Relatedness was inferred by the neighbor-joining method (Saitou \& Nei 1987), and strength of the tree was tested by bootstrapping $(n=1000)$. The final tree was condensed to branches reproduced greater than $40 \%$ of the time. All sequences derived from this study have been deposited in GenBank.

Statistical analysis. The size of fish examined at OIFC and at TI was compared using fish TL. Transformed and non-transformed data were tested for normal distribution (Shapiro-Wilk) and homogeneity of variance (Bartlett), and having failed those tests, TL data of each population and gender were compared using non-parametric 1-way analysis of variance (ANOVA; Wilcoxon rank sum). Sex ratios of OIFC and TI populations were compared using a Pearson chisquared test.

Percent concordance for presence of $\mathrm{AF}+$ bacilli within granulomas was determined between $\mathrm{ZN}$ - and PZN-stained tissues. The proportion of fish with splenic AF+ granulomas was compared between ZNand PZN-stained tissues using NcNemar's test (Durkalski et al. 2003), which is useful to test for matched-pair treatment effects.

Capture site, gender, and fish TL were tested for their effects on (1) presence or absence of splenic granulomas using logistic regression, and (2) granuloma density using ANOVA with general linear models. Logistic regression was based on a generalized linear model that assumed a binomial distribution and a logit link function. Main effects and all interaction terms were included in each analysis. Categorical data were also compared in some instances using Fisher's exact 
test with Bonferroni correction. Tests were performed using SAS Enterprise Guide 4.1, and differences were considered significant when $\mathrm{p}<0.05$ in all analyses (Davis 2007).

\section{RESULTS}

A total of 249 striped bass (201 female, 48 male), ranging in TL from 720 to $1190 \mathrm{~mm}$ (mean $\pm \mathrm{SD}=911$ $\pm 89 \mathrm{~mm}$, median $=907 \mathrm{~mm}$ ), were examined at OIFC, and 120 fish (100 female, 20 male), ranging in TL from 749 to $1041 \mathrm{~mm}(890 \pm 55 \mathrm{~mm}$, median $=876 \mathrm{~mm})$, were examined at TI. The median TL of fish from OIFC was significantly larger (Wilcoxon rank sum, $\mathrm{df}=1, \mathrm{p}=$ 0.0165) than median TL of fish from TI, but the sex ratios of the 2 groups of fish were not significantly different (chi-squared test, $\mathrm{df}=1, \mathrm{p}=0.5703$ ).

Granulomas of variable size and morphology were present in the spleen of $18.5 \%$ of OIFC and $18.3 \%$ of TI fish. The majority of AF+ granulomas consisted of an outer layer of epithelioid cells, an inner layer of spindle cells, and a single central core of necrotic debris with few, scattered 2 to $4 \mu \mathrm{m}$ bacilli (Fig. 2a). Occasionally, cells with pyknotic or karyorrhectic nuclei, small clusters of bacilli, or rounded forms of acid-fast bacteria were found in the necrotic cores. Variable amounts of melanin were often evident in $\mathrm{AF}+$ granulomas, either clustered along the outer margin of the epithelioid layer, within the necrotic core, or scattered within the epithelioid or spindle layers (Fig. 2a,c,d,e). Ceroid or lipofuscin pigments were also found occasionally in the necrotic cores (Fig. 2a,c,d). Diameter of AF+ granulomas varied from 150 to $650 \mu \mathrm{m}$, and larger granulomas tended to have a single primary core with 1 to several smaller secondary cores within the epithelioid layers (Fig. 2b).

Concordance was $92 \%$ for $\mathrm{AF}+$ bacilli between $\mathrm{ZN}$ - and PZN-stained tissues among $\mathrm{AF}+$ fish, and the prevalence of fish with $\mathrm{AF}+$ granulomas was not significantly different between $\mathrm{ZN}$ - and PZN-stained tissues (McNemar, $\mathrm{df}=1, \mathrm{p}=0.1573$ ). Also, qualitative observations of $\mathrm{AF}+$ granulomas from $\mathrm{ZN}$ - and PZN-stained tissues indicated no apparent differences in the amount of acid-fast bacilli between these staining protocols. In comparison to $\mathrm{ZN}$, staining with PZN resulted in darker background and increased non-specific staining within the splenic parenchyma, digenean metacercariae, and infrequently in epithelioid and spindle layers of granulomas.
Fig. 2. Morone saxatilis. Granuloma morphology in spleen of striped bass collected at Oregon Inlet, Manteo, North Carolina (December 2005 to February 2006) and Tilghman, Maryland (April to May 2006), USA. (a) Acid-fast positive $(\mathrm{AF}+)$ granuloma with incomplete outer layer of melanin and lipofuscin/ceroid pigments within a necrotic core (ZiehlNeelsen [ZN] stain). (b) AF+ granuloma with multiple secondary cores within the epithelioid layer (ZN stain). (c) AF+ granuloma with greatly reduced epithelioid layer (ZN stain pre-treated with $10 \%$ periodic acid $[\mathrm{PZN}]$ stain). (d) AF+ granuloma within mesentery adjacent to the spleen (ZN stain). (e) AF- granuloma with large inner core of concentric spindle cell layers (ZN stain). (f) Granuloma containing encysted digenean metacercariae (hematoxylin and eosin stain). Scale bar $=100 \mu \mathrm{m}$. All plates are at the same magnification

Size and morphology of AF-granulomas were generally similar to those of AF+ granulomas. However, some AF-granulomas were smaller than $150 \mu \mathrm{m}$ and consisted primarily of an outer layer of epithelioid cells with a central core of necrotic cells and cellular debris. Occasionally, AF- granulomas were found with a reduced outer layer of epithelioid cells with a large core of concentric layers of spindle cells (Fig. 2e). Small, scattered clusters of melanin were the only pigments found, and no cellular debris was evident in these types of AF-granulomas (Fig. 2e).

Parasites associated with PG were predominantly digenean metacercariae (Fig. 2f), but also included unidentified cestodes and nematodes. Granulomatous reaction to splenic parasites was typically mild and included a thin epithelioid layer surrounding a fibrous capsule. Acid-fast stained bacteria were not evident in any $P G$.

Overall, the prevalence of striped bass with granulomas in the spleen was $6.7 \%(\mathrm{AF}+), 17.9 \%(\mathrm{NPG})$, and $7.6 \%$ (PG) (Table 1). Results of logistic regression indicated that there were no significant effects of site, fish

Table 1. Morone saxatilis. Prevalence of splenic granulomas from striped bass examined at the Oregon Inlet Fishing Center (OIFC) during the winter recreational fishery in North Carolina and at a fillet station on Tilghman Island (TI) during the spring recreational fishery in Chesapeake Bay, Maryland. AF+: with acid-fast bacilli, NPG: non-parasitic granulomas, PG: parasitic granulomas. Median fish lengths with different upper-case superscripts $(A, B)$ denote significant differences $(p<0.05)$. Significant effects of location, gender, or fish length on prevalence of each granuloma category were not detected with logistic regression

\begin{tabular}{|c|c|c|c|c|c|c|}
\hline \multirow{2}{*}{ Location } & \multirow[t]{2}{*}{$\mathrm{n}$} & \multirow{2}{*}{ Sex } & \multirow{2}{*}{$\begin{array}{l}\text { Median length } \\
\text { (quartiles) }\end{array}$} & \multicolumn{3}{|c|}{ Fish with granulomas (\%) } \\
\hline & & & & $\mathrm{AF}+$ & NPG & PG \\
\hline \multirow[t]{2}{*}{ OIFC } & 201 & Female & $920^{\mathrm{A}}(870,970)$ & $4.5^{\mathrm{a}}$ & 13.9 & 6.0 \\
\hline & 48 & Male & $850^{\mathrm{B}}(810,890)$ & $12.5^{\mathrm{a}}$ & 33.3 & 22.9 \\
\hline \multirow[t]{2}{*}{ TI } & 100 & Female & $876^{\mathrm{B}}(857,939)$ & $8.0^{\mathrm{a}}$ & 19.0 & 4.0 \\
\hline & 20 & Male & $863^{\mathrm{B}}(838,908)$ & 10.0 & 15.0 & 5.0 \\
\hline Overall & 369 & & & 6.8 & 17.9 & 7.8 \\
\hline
\end{tabular}



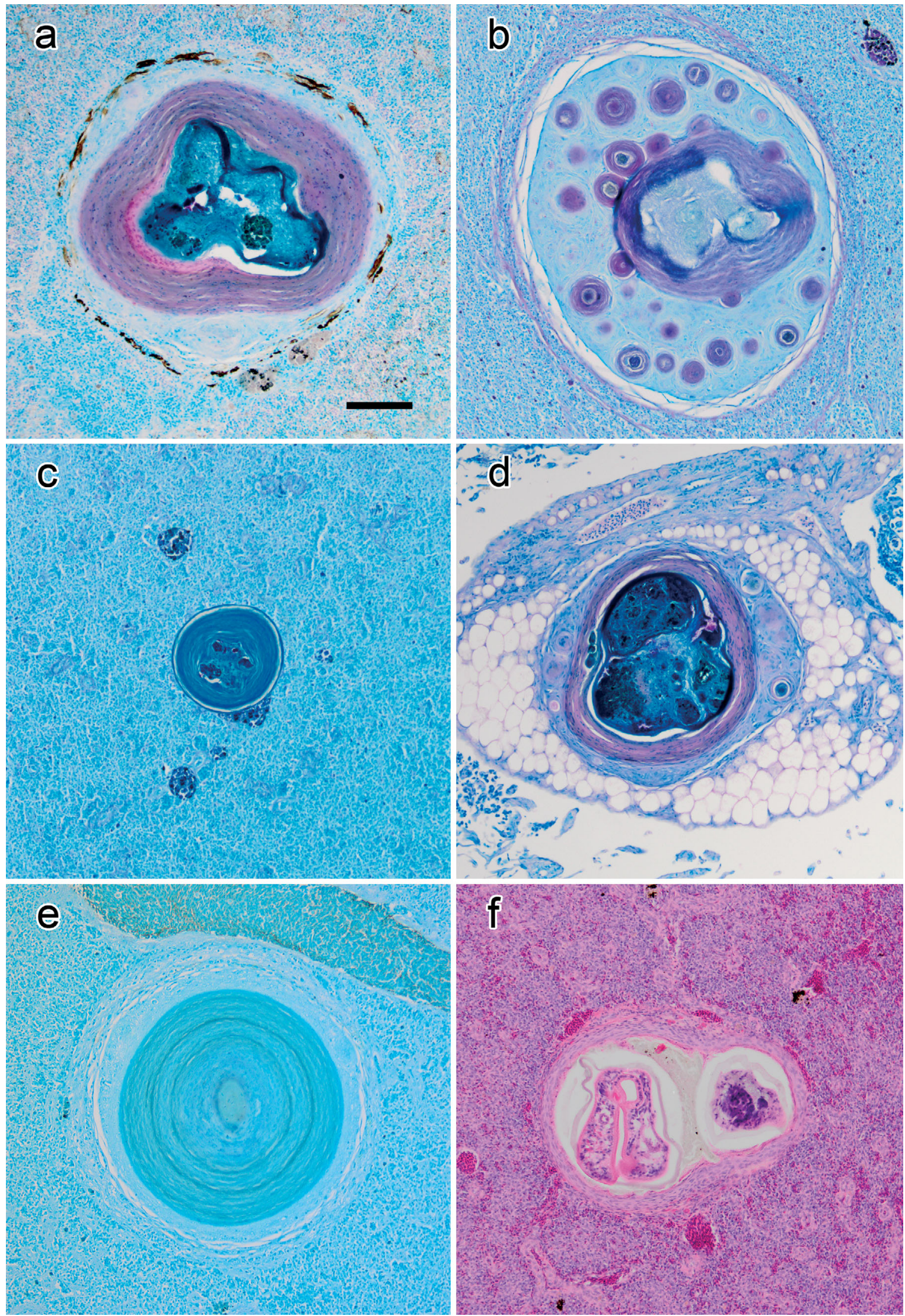
gender, or TL on prevalence of AF+ granulomas (experiment-wide Wald $\chi^{2}=7.9698, \mathrm{df}=6, \mathrm{p}=0.1207$ ), NPG (experiment-wide Wald $\chi^{2}=12.3451, \mathrm{df}=6, \mathrm{p}=0.0547$ ), and PG (experiment-wide Wald $\chi^{2}=10.7601, \mathrm{df}=6, \mathrm{p}=$ 0.0966). Prevalence of NPG in male OIFC fish was significantly higher than in female OIFC fish $(p=0.0029)$ but was not significantly different than in male $(p=0.1497)$ or female TI fish $(p=0.0646)$. Prevalence of PG in male OIFC fish was significantly higher than in female OIFC (Fisher's exact, $\mathrm{df}=2, \mathrm{p}=0.0010$ ) and female TI fish (Fisher's exact, $d f=2, p=0.0008$ ), but it was not significantly different than in male TI fish (Fisher's exact, $d f=2, p=0.0936$ ).

Density of splenic AF+ granulomas was $0.0224 \pm 0.0081$ (SEM) in TI fish and $0.0281 \pm 0.0064$ in OIFC fish. When including $\mathrm{AF}-$ granulomas (NPG), the density increased to 0.0287 \pm 0.0067 in TI fish and to $0.0461 \pm$ 0.0089 in OIFC fish. Density of PG was $0.0154 \pm 0.0045$ in TI fish and $0.0290 \pm$ 0.0092 in OIFC fish. ANOVA results indicated no significant effects of TL, gender of fish, or site on the density of $\mathrm{AF}+$ granulomas $(F=1.14, \mathrm{df}=21, \mathrm{p}=$ $0.3883)$, NPG $(F=0.94, \mathrm{df}=65, \mathrm{p}=$ $0.4713)$, and $\mathrm{PG}(F=1.19, \mathrm{df}=27, \mathrm{p}=$ 0.3472).

Eight AF+ samples were subjected to genus-level real-time PCR (Bruijnesteijn van Coppenraet et al. 2004, Jacobs et al. 2009b, Stine et al. 2009) for speciation of mycobacteria. Sequences obtained from the 16-23S ITS region suggest a cladic relationship among bacteria from the migratory stock (Fig. 3). Bootstrapping demonstrated that this relationship holds $72 \%$ of the time. Similarity among these sequences ranged from 82 to $100 \%$, but none matched any published sequence (GenBank).

\section{DISCUSSION}

Samples collected in Chesapeake Bay and off the coast of North Carolina in this study had a lower prevalence of disease $(6.8 \%)$ compared to previous reports from smaller pre-migratory fish in Chesapeake Bay. The prevalence of mycobacteriosis reported here is based on the observation of $\mathrm{AF}+$ bacilli within granulomas, which is consid- ered a conservative diagnostic approach (Gauthier et al. 2003, Kaattari et al. 2005). Disease prevalence may be as high as $17.6 \%$ (\% NPG, see Table 1) in these fish because $\mathrm{AF}+$ bacilli are not always evident in granulomas (Gauthier et al. 2003). However, parasites are not always evident in PG when sectioned at the margins, and other pathogens are known to elicit granulomatous inflammation. Overton et al. (2003) found visceral granulomas in $53 \%$ of striped bass (290 to $2270 \mathrm{~mm} \mathrm{TL}$, $44 \%$ were $<457 \mathrm{~mm}$ TL) collected during 1998 to 1999 from Maryland's Chesapeake Bay. Gauthier et al.

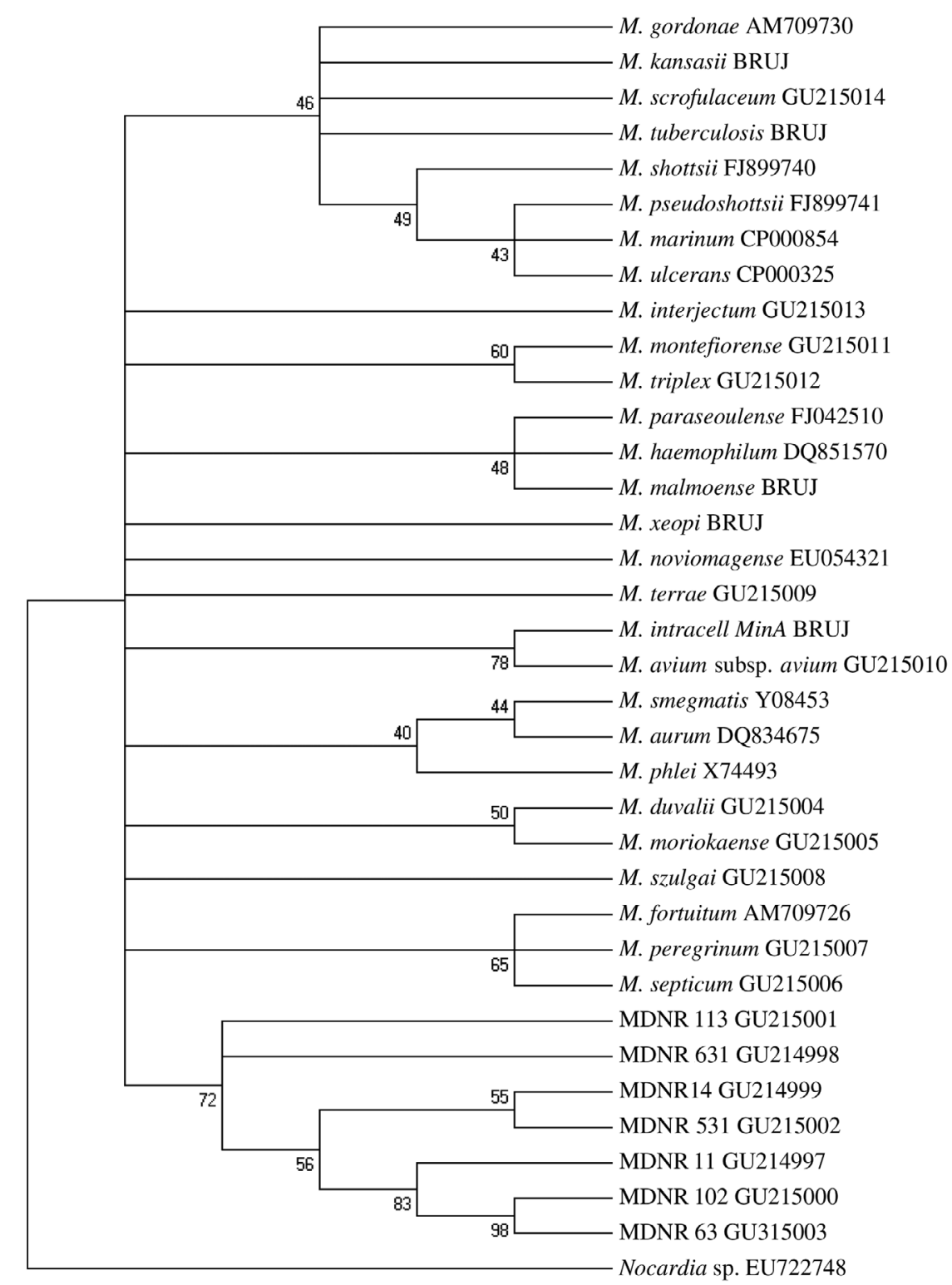

Fig. 3. Mycobacterium spp. Bootstrap consensus tree $(n=1000)$ derived from the neighbor-joining method for the 16-23S intergenic transcribed spacer (ITS) region of select species of mycobacteria and sequences obtained in this study (labeled MDNR). Branches corresponding to partitions reproduced in less than $50 \%$ bootstrap replicates are collapsed 
(2008) reported that splenic granuloma prevalence increased with age-class in fish collected from Maryland and Virginia waters during 2003 to 2005, from about $20 \%$ in Age 1 to $>80 \%$ in Age 5 fish. After Age 5, prevalence remained high in males and $>30 \%$ in all females except Age 9 fish (Gauthier et al. 2008).

Logistic regression analysis failed to find significant affects of gender, location, or fish size on prevalence of mycobacteriosis. In contrast, Gauthier et al. (2008) found markedly higher prevalence of mycobacteriosis in Age 5+ male fish from Chesapeake Bay. Although disease prevalence in migratory striped bass may not differ between males and females, power analysis indicates that it is likely that insufficient samples were examined in this study to detect a difference (Hsieh 1989).

Results of this study may indicate an increased prevalence of parasitic granulomas in male OIFC fish. While the probabilities that gender and location had an effect on prevalence of PG ( $p=0.0966)$ and NPG ( $p=$ 0.0547 ) were borderline but not significant, multiple Fisher's exact test comparisons indicated a significantly higher prevalence of these granuloma categories in male than in female OIFC fish. The increased prevalence of NPG in male OIFC fish was likely driven by increased prevalence of PG that could not be differentiated as such in tissue sections. Encapsulated parasites are occasionally dislodged during tissue processing, leaving hollow granulomas, and tissues sectioned at the margins of granulomas may lack parasitic tissues.

This is the first examination of migratory striped bass for prevalence of splenic mycobacteriosis. A portion of striped bass from the Chesapeake Bay undergo annual migrations northward to as far as New England in the spring and southward to as far as North Carolina in the winter, reentering the Chesapeake Bay in late winter and spring to spawn (Kohlenstein 1981, Boreman \& Lewis 1987, Secor \& Piccoli 2007). The recreational fishing season for striped bass in winter and early spring in Chesapeake Bay and coastal North Carolina predominantly targets migratory fish. The minimum legal take size in these fisheries was $711 \mathrm{~mm}$, which biased the size of fish examined in this study towards larger fish. However, this size bias also reduced the likelihood of pre-migratory fish resident to Chesapeake Bay or Albemarle Sound being included in this study. It is also possible that disease state may affect the relative proportion of striped bass captured using hook-and-line techniques, resulting in a bias towards healthy fish in this study. It is unlikely that a bias based on capture method alone would have resulted in the markedly lower estimate of apparent prevalence of mycobacteriosis reported here compared to reports in Chesapeake Bay. Overton et al. (2003) and Kaattari et al. (2005) also employed hook-and-line capture techniques and found $>50 \%$ prevalence in Chesapeake Bay.

Mycobacteriosis has also been reported in striped bass from estuaries outside the Chesapeake Bay. Visceral granulomas (spleen, liver, and kidney) with acidfast bacilli were found in striped bass from Roanoke River (18\% of 60 fish), North Carolina, in April 2003 (Ottinger \& Jacobs 2006) and Delaware Bay (6.25\% of 80 fish), Delaware, in December 2003 (Ottinger et al. 2007), and ongoing efforts suggest approximately $20 \%$ in Long Island Sound (M. Fast pers. comm.). Also, multiple species of Mycobacterium were isolated from striped bass from Albemarle Sound, Delaware Bay, and Long Island Sound (Ottinger et al. 2007, Stine et al. 2009). Chesapeake Bay stock contribute a high proportion of fish to the mixed coastal striped bass population (Berggren \& Lieberman 1978, Wirgin et al. 1993), and while transmission modes of mycobacteriosis are unknown, intermixing of fish from multiple stocks during annual migrations leaves open the possibility of transmission of this disease to Roanoke River and Hudson River populations.

The lower prevalence of disease in migratory striped bass compared to resident Chesapeake Bay fish reported here may indicate increased disease-associated mortality in larger fish. Gauthier et al. (2008) provided the first evidence of mycobacteriosis-associated mortality in striped bass using force-of-infection models, which allows the estimate of a disease-associated mortality hazard based on age-prevalence data. There is evidence that natural mortality, a measure of fisheryindependent mortality, has increased in the Chesapeake Bay striped bass population beginning in 1999 (Jiang et al. 2007), soon after mycobacteriosis was widely apparent in Chesapeake Bay (Heckert et al. 2001, Rhodes et al. 2001). However, within natural mortality estimates, disease-associated mortality cannot be distinguished from losses due to predation or senescence. Force-of-infection models assume that disease is irreversible. An alternate hypothesis is that the decline in disease prevalence among migratory fish reported here resulted from resolution of visceral granulomas.

There is some evidence of lesion regression in experimental infections. Colorni et al. (1998) noted that size and number of splenic granulomas regressed in sea bass Dicentrarchus labrax following experimental infection with Mycobacterium marinum, but M. marinum is infrequently isolated from Chesapeake Bay striped bass (Rhodes et al. 2004, Stine et al. 2010) and was not identified by PCR and subsequent sequencing from fish in this study. The number of mesenteric granulomas regressed in striped bass experimentally infected with M. shottsii (Gauthier et al. 2003), the 
most commonly isolated species from Chesapeake Bay striped bass (Rhodes et al. 2004, Stine et al. 2010). However, disease dynamics may differ between experimental and natural infections; splenic granulomas were rare in $M$. shottsii-infected fish in the study by Gauthier et al. (2003), but are the characteristic lesion in diseased Chesapeake Bay striped bass (Jacobs et al. 2009c). More work is therefore needed to determine to what extent lesions resolve in natural mycobacterial infections, which is important because apparent prevalence of disease and hence survival ratio models are based on histological diagnosis.

Inclusion of Hudson River or Roanoke River-Albemarle Sound stock in fish examined in this study may have contributed to the low disease prevalence reported here. Prevalence of mycobacteriosis is markedly lower in Hudson and Roanoke River striped bass, and intermixing with Chesapeake Bay fish may have a dilution effect on disease prevalence. Although the stock origin of fish examined in this study is unknown, it is likely that fish, and particularly TI fish, were predominantly Chesapeake Bay stock (Wirgin et al. 1993).

Water temperature may have an influence on estimation of apparent prevalence of mycobacteriosis in fish. The growth of mycobacteria in infected fish may decrease with decreasing water temperature (Clark \& Shepard 1963); therefore, bacterial abundance and the ability to visualize acid-fast bacteria in granulomas may be reduced in fish from colder water. The majority of fish examined in this study were collected from OIFC in winter, whereas high disease prevalence of pre-migratory striped bass from Chesapeake Bay was reported from fish examined from spring to fall when water temperatures were likely higher (Overton et al. 2003, Gauthier et al. 2008). Host cellular response (i.e. granulomatous inflammation), however, is generally temperature independent in fish (Magnadóttir 2006). While disease prevalence reported here is based on observation of AF+ granulomas, analysis of NPG (see Table 1) offers a less conservative estimate of disease prevalence based solely on host cellular response rather than visualization of acid-fast bacteria. Results of NPG analysis in this study indicated that disease prevalence remained low $(<18 \%)$ and that there was no significant difference between OIFC (examined in winter) and TI fish (examined in spring), suggesting that temperature was not an important factor in determining disease prevalence by acid-fast staining in this study.

Genus-level PCR and subsequent sequencing of the 16-23S ITS region indicated that mycobacteria from Chesapeake Bay and North Carolina fish were phylogenetically related, but are all unknown species. There are over 120 known species of mycobacteria, of which 13 have been reported cultured from fish (Jacobs et al. 2009c). However, it is not uncommon to isolate unidentified species from striped bass. Stine et al. (2010) found that nearly one-third of the isolates from Chesapeake Bay striped bass were not identifiable. Perhaps of more interest in this study is the apparent absence of Mycobacterium shottsii. The recently described $M$. shottsii is by far the predominant isolate from Chesapeake Bay striped bass (Rhodes et al. 2004, Stine et al. 2010). Previously known only from Chesapeake Bay striped bass, M. shottsii was recently detected in striped bass from Albemarle Sound and Long Island (Stine et al. 2009), Delaware Bay striped bass (Ottinger et al. 2007), and from Chesapeake Bay white perch Morone americana (Stine et al. 2009). It is interesting that this species is recovered from striped bass in other regions, yet disease prevalence is much lower, which may point to differences in disease susceptibility or disease-associated mortality between Chesapeake Bay fish and fish resident to other estuaries (Roanoke River, Delaware Bay, and Long Island). Further monitoring for disease in striped bass from other regions is needed to determine disease prevalence dynamics.

Prevalence and intensity of mycobacteriosis in Chesapeake Bay striped bass appears to be unique. Prevalence of mycobacteriosis $>50 \%$ has been reported from Chesapeake Bay (Overton et al. 2003, Kaattari et al. 2005), whereas prevalence $\leq 20 \%$ was observed in striped bass resident to estuaries outside Chesapeake Bay (Ottinger \& Jacobs 2006, Ottinger et al. 2007) and was $6.8 \%$ in coastal migratory fish (present study). In addition, granulomatous inflammation was mild in all diseased striped bass examined in the present study, but moderate and severe forms of disease are not uncommon in Chesapeake Bay (Kaattari et al. 2005). It is not known why prevalence and intensity of mycobacteriosis in striped bass is higher in Chesapeake Bay. Decline in nutritional state (Jacobs et al. 2009a) and reduced suitable habitat during summer (e.g. elevated surface water temperatures and anoxia at depth; Coutant 1985) have been proposed for high disease prevalence in Chesapeake Bay striped bass. More work is needed to better understand stressors and other factors that may be contributing to elevated prevalence of visceral mycobacteriosis in Chesapeake Bay. We recommend continued monitoring to follow the course of this disease in the migratory stock, and studies of disease progression (e.g. mark-recapture studies) may reveal the extent of disease resolution versus mortality.

Acknowledgements. We thank W. Laney (United States Fish and Wildlife Service), H. King (Maryland Department of Natural Resources), and J. Price (Chesapeake Bay Ecological Foundation) for their financial support. We also thank personnel at the Oregon Inlet Fishing Center, particularly 
M. Swain, for use of their facilities; and J. Clermont, M. Butler, C. Lee, and N. Jones for assisting in the field collections. We also thank $\mathrm{H}$. Townsend for assistance with statistical analysis; J. Blazek, S. Lehmann, and S. Tyler for tissue processing; and D. Howard for processing samples for PCR analysis.

\section{LITERATURE CITED}

Berggren T, Lieberman J (1978) Relative contribution of Hudson, Chesapeake, and Roanoke striped bass, Morone saxatilis, stocks to the Atlantic coast fishery. Fish Bull 76: 335-345

Boreman J, Lewis R (1987) Atlantic coastal migration of striped bass. Am Fish Soc Symp 1:331-339

Bruijnesteijn van Coppenraet ES, Lindeboom JA, Prins JM, Peeters MF, Claas ECJ, Kuijper EJ (2004) Real-time PCR assay using fine-needle aspirates and tissue biopsy specimens for rapid diagnosis of mycobacterial lymphadenitis in children. J Clin Microbiol 42:2644-2650

> Chapoton R, Sykes J (1961) Atlantic coast migration of large striped bass as evidenced by fisheries and tagging. Trans Am Fish Soc 90:13-20

> Clark H, Shepard C (1963) Effect of environmental temperatures on infection with Mycobacterium marinum (Balnei) of mice and a number of poikilothermic species. J Bacteriol 86:1057-1069

Colorni A, Avtalion R, Knibb W, Berger E, Colorni B, Timan B (1998) Histopathology of sea bass (Dicentrarchus labrax) experimentally infected with Mycobacterium marinum and treated with streptomycin and garlic (Allium sativum) extract. Aquaculture 160:1-17

Coutant C (1985) Striped bass, temperature, and dissolved oxygen: a speculative hypothesis for environmental risk. Trans Am Fish Soc 114:31-61

Davis J (2007) Statistics using SAS enterprise guide. SAS Institute Inc., Cary, NC

> Dorazio R, Hattala K, McCollough C, Skjeveland J (1994) Tag recovery estimates of migration of striped bass from spawning areas of the Chesapeake Bay. Trans Am Fish Soc 123:950-963

Durkalski V, Palesch Y, Lipsitz S, Rust P (2003) Analysis of clustered matched-pair data. Stat Med 22:2417-2428

> Gauthier DT, Rhodes MW, Vogelbein WK, Kator H, Ottinger CA (2003) Experimental mycobacteriosis in striped bass Morone saxatilis. Dis Aquat Org 54:105-117

> Gauthier DT, Latour RJ, Heisey DM, Bonzek CF, Gartland J, Burge EJ, Vogelbein WK (2008) Mycobacteriosis-associated mortality in wild striped bass (Morone saxatilis) from Chesapeake Bay, USA. Ecol Appl 18:1718-1727

Hall TA (1999) BioEdit: a user-friendly biological sequence alignment editor and analysis program for Windows 95/98/NT. Nucleic Acids Symp Ser 41:95-98

> Heckert R, Elankumaran S, Milani A, Baya A (2001) Detection of a new Mycobacterium species in wild striped bass in the Chesapeake Bay. J Clin Microbiol 39:710-715

Hsieh F (1989) Sample size tables for logistic regression. Stat Med 8:795-802

Jacobs J, Rhodes M, Baya A, Reimschuessel R, Townsend H, Harrell R (2009a) Influence of nutritional state on the progression and severity of mycobacteriosis in striped bass Morone saxatilis. Dis Aquat Org 87:183-197

Jacobs JM, Howard D, Rhodes MR, Newman M, May EB, Harrell RM (2009b) Historical presence (1975-1985) of mycobacteriosis in Chesapeake Bay striped bass Morone saxatilis. Dis Aquat Org 85:181-186

Jacobs JM, Stine CS, Baya AM, Kent ML (2009c) A review of mycobacteriosis in marine fish. J Fish Dis 32:119-130

Jiang H, Pollock K, Brownie C, Hoenig J, Latour R, Wells B, Hightower J (2007) Tag return models allowing for harvest and catch and release: evidence of environmental and management impacts on striped bass fishing and natural mortality rates. N Am J Fish Manag 27:387-396

Kaattari IM, Rhodes MW, Kator H, Kaattari SL (2005) Comparative analysis of mycobacterial infections in wild striped bass Morone saxatilis from Chesapeake Bay. Dis Aquat Org 67:125-132

> Kohlenstein L (1981) On the proportion of Chesapeake Bay stock of striped bass that migrates into the coastal fishery. Trans Am Fish Soc 110:168-179

Magnadóttir B (2006) Innate immunity of fish (overview). Fish Shellfish Immunol 20:137-151

Mansueti R (1961) Age, growth, and movements of the striped bass, Roccus saxatilis, take in size selective fishing gear in Maryland. Chesap Sci 2:209-212

Nyka W, O'Neill E (1970) A new approach to the study of nonacid-fast mycobacteria. Ann NY Acad Sci 174:862-871

Ottinger CA, Jacobs JM (2006) USGS/NOAA workshop on mycobacteriosis in striped bass. NOAA Tech Memo NOS NCCOS 41, Annapolis, MD

Ottinger C, Brown J, Densmore C, Starliper C and others (2007) Mycobacterial infections in striped bass from Delaware Bay. J Aquat Anim Health 19:99-108

> Overton AS, Margraf FJ, Weedon CA, Pieper LH, May EB (2003) The prevalence of mycobacterial infections in striped bass in Chesapeake Bay. Fish Manag Ecol 10: 301-308

Presnell J, Schreibman M (1997) Humason's animal tissue techniques. The Johns Hopkins University Press, Baltimore, MD

Rhodes MW, Kator H, Kotob S, Van Berkum P and others (2001) A unique Mycobacterium species isolated from an epizootic of striped bass (Morone saxatilis). Emerg Infect Dis 7:896-899

> Rhodes MW, Kator H, Kaattari I, Gauthier D, Vogelbein W, Ottinger CA (2004) Isolation and characterization of mycobacteria from striped bass Morone saxatilis from the Chesapeake Bay. Dis Aquat Org 61:41-51

> Saitou N, Nei M (1987) The neighbor-joining method: a new method for reconstructing phylogenetic trees. Mol Biol Evol 4:406-425

Secor D, Piccoli P (2007) Oceanic migration rates of Upper Chesapeake Bay striped bass (Morone saxatilis), determined by otholith microchemical analysis. Fish Bull 105: $62-73$

Stine C, Jacobs J, Rhodes M, Overton A, Fast M, Baya A (2009) Expanded range and new host species of Mycobacterium shottsii and M. pseudoshottsii. J Aquat Anim Health 21:179-183

Stine C, Kane A, Baya A (2010) Mycobacteria isolated from Chesapeake Bay fish. J Fish Dis 33:39-46

Tamura K, Dudley J, Nei M, Kumar S (2007) MEGA4: molecular evolutionary genetics analysis (MEGA) software version 4.0. Mol Biol Evol 24:1596

- Wirgin I, Maceda L, Waldman J, Crittenden R (1993) Use of mitochondrial DNA polymorphisms to estimate the relative contributions of the Hudson River and Chesapeake Bay striped bass stocks to the mixed fishery on the Atlantic coast. Trans Am Fish Soc 122:669-684 